\title{
Editorial
}

The Editorial Introduction to the very first issue of Cambridge Opera Joumal (March 1989) was admirably plain, modest and brief. As I take over the editorship from Art Groos and Roger Parker, that is only the first thing I will try to emulate. The second is the anything but modest scope of the publication itself. Although 'multivalent' was before 1989 a word quite commonly applied to opera, Roger's and Art's assemblage of essays over the years has shown that opera welcomes scholarly consideration not only as written words and music whose formal systems work both in concert and at odds with each other, but as performed sounds from performing bodies, as a genre both akin to and distinct from literature, and as a place where anxieties - and certainties - about life, death, disease, sex, gender, race, ethnicity and class are played out. If opera itself is multivalent, the methods used to study it, as they are represented in this journal, have been commensurately inter- and multi-disciplinary, as Art and Roger wished. Biography, source-study, analysis, history, semiology, narratology, psychology and philosophy rub shoulders with each other, as do scholars from a variety of countries, a wide assortment of institutions, and all stages of professional life. All readers of the journal owe Roger and Art an enormous debt for bringing this cornucopia to us; contributors can (I happen to know) thank them for extraordinarily careful and comprehensive editing.

As the journal moves into its second phase, my able and enthusiastic associate editors and I hope to continue the broad reach and interdisciplinary aspect of the journal (though perhaps not to the extent of its becoming 'Cable Jumpers' Journal' as a colleague of mine recently mis-heard the name). We welcome essays on musical theatre of many sorts from a variety of perspectives, and undertake to uphold the high standards of thinking and writing that the founding editors initiated.

\section{MARY HUNTER}

